\title{
Hydrologic Conditions in Massachusetts During Water Year 2014
}

Open-File Report 2015-1056 



\section{Hydrologic Conditions in Massachusetts During Water Year 2014}

By Richard J. Verdi

Open-File Report 2015-1056 


\section{U.S. Department of the Interior \\ SALLY JEWELL, Secretary}

\section{U.S. Geological Survey \\ Suzette M. Kimball, Acting Director}

U.S. Geological Survey, Reston, Virginia: 2015

For more information on the USGS - the Federal source for science about the Earth, its natural and living resources, natural hazards, and the environment—visit http://www.usgs.gov/ or call 1-888-ASK-USGS.

For an overview of USGS information products, including maps, imagery, and publications,

visit http://www.usgs.gov/pubprod/.

Any use of trade, firm, or product names is for descriptive purposes only and does not imply endorsement by the U.S. Government.

Although this information product, for the most part, is in the public domain, it also may contain copyrighted materials as noted in the text. Permission to reproduce copyrighted items must be secured from the copyright owner.

Suggested citation:

Verdi, R.J., 2015, Hydrologic conditions in Massachusetts during water year 2014: U.S. Geological Survey Open-File Report 2015-1056, 10 p., http://dx.doi.org/10.3133/ofr20151056.

ISSN 2331-1258 (online) 


\section{Contents}

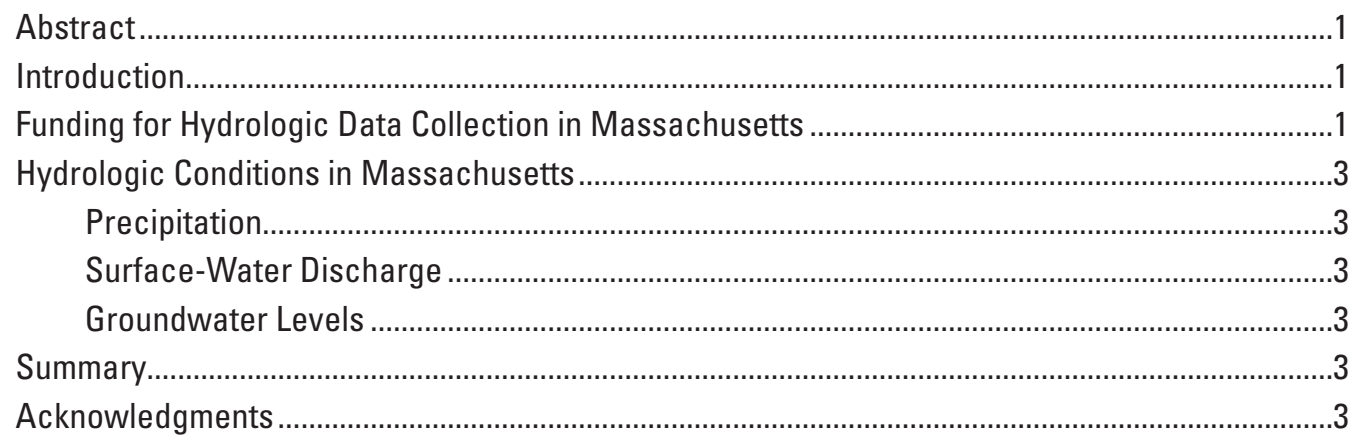

\section{Figures}

1. Map and table showing Massachusetts monitoring stations referenced

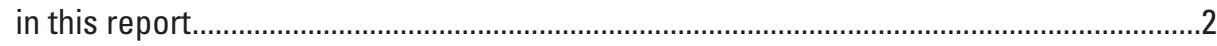

2. Graphs showing average annual cumulative precipitation versus cumulative precipitation during water year 2014 for $A-F$, regions and $G$, the entire State of Massachusetts......................................................................................................................

3. Graphs showing discharge hydrographs for the six representative streams in

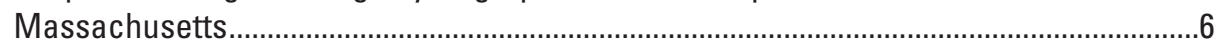

4. Graph showing groundwater hydrographs for the eight representative wells in

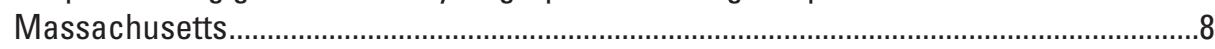

\section{Tables}

2. Record-minimum monthly mean discharges in Massachusetts during water year 2014 compared with the previous records for the period of record.

1. Mean annual discharge of selected streams in Massachusetts for water years 2014 and 2013 and for the period of record 



\title{
Hydrologic Conditions in Massachusetts During Water Year 2014
}

\author{
By Richard J. Verdi
}

\section{Abstract}

Hydrologic data and conditions throughout Massachusetts during water year 2014 (October 1, 2013, to September 30, 2014) are presented in this report. Stream discharge and groundwater levels during water year 2014 varied geographically across the State. The data are described as being above, below, or near normal in relation to long-term averages for the period of record.

\section{Introduction}

Before 1960, hydrologic data collected by the U.S. Geological Survey (USGS) in Massachusetts were published in various water-supply papers and included water-related data collected by USGS during a water year ${ }^{1}$. In 1961, a series of annual reports titled "Water-Resources Data for Massachusetts" was introduced; these reports contained only surface-water data. In 1964, a similar report was introduced for the purpose of publishing water-quality data. In 1975, surface-water data, water-quality data, and groundwater levels were published in a single volume annual report. Formal publication of the annual report series was discontinued at the end of water year 2004. Reports describing data collected after water year 2004 through water year 2013 are available as site data sheets from the annual data report Web site (http://wdr.water. usgs.gov/), which facilitates the retrieval of reports for stations throughout the United States. Beginning with water year 2014, reports describing data collected during the water year are being published as annual water summaries and are available from the USGS National Water Information System (NWIS) Water Data for the Nation Web site (http://waterdata.usgs.gov/ma/nwis/nwis).

Current and historical data, including site information, daily values, statistics, and field measurements, are available for all monitoring stations on the USGS NWIS Web site. In this report, monitoring station refers to a streamgage, groundwater well, or precipitation gage. Instantaneous time-series data for the past 10 to 15 years are available for many characteristics, including gage height, discharge, water temperature, specific conductance, and other parameters, through the Instantaneous Data Archive (http://ida.water.usgs.gov/ida/index_usgs.cfm). As a result of the

\footnotetext{
${ }^{1} \mathrm{~A}$ water year is the 12 -month period beginning October 1 and ending September 30. It is designated by the year in which it ends.
}

evolution of electronic data loggers, computer systems have made it possible to store and provide access to such data for many USGS monitoring stations. These instantaneous time-series data are typically recorded at intervals of 60 minutes or less and are the basis for computations of daily values for discharge, water level, and other hydrologic variables.

This report summarizes hydrologic data and conditions at representative wells and stream sites throughout Massachusetts for water year 2014. Precipitation, discharge, and water-level values are shown in figures. Discharge values are listed in tables.

\section{Funding for Hydrologic Data Collection in Massachusetts}

Funding to provide hydrologic data to the public primarily comes from four sources: (1) the USGS Cooperative Water Program, in which the USGS, State, local, and municipal agencies share in the costs of the monitoring stations; (2) Federal, State, and local agencies and private entities without cost sharing; (3) the National Streamflow Information Program (NSIP); and (4) the Collection of Basic Records (CBR) Program. The USGS Cooperative Water Program funds most of the monitoring stations in Massachusetts through cost-sharing agreements with several State agencies and many local, county, and municipal governments. The NSIP provides some Federal funding for streamgages with one or more of the following critical interests: interstate and international waters, flood forecasts, large riverbasin outflows, sentinel watersheds, and water quality. The CBR program provides some Federal funding for a basic network of groundwater monitoring wells across the Nation.

During water year 2014, funding was received for the collection of hydrologic data from 97 continuous-discharge streamgages, 13 stage-only streamgages and lake stations, 29 continuous-monitoring groundwater stations, 57 month-end groundwater-level stations in the USGS Climate Response Network, and 72 month-end groundwater-level stations in the USGS Active Water Level Network. Continuous water-quality data were collected at three stations. Real-time data for all of the continuous-record stations are available through NWIS (http://waterdata.usgs.gov/ma/nwis/rt/). The locations of the monitoring streamgages and groundwater stations referenced in this report are identified in figure 1. 


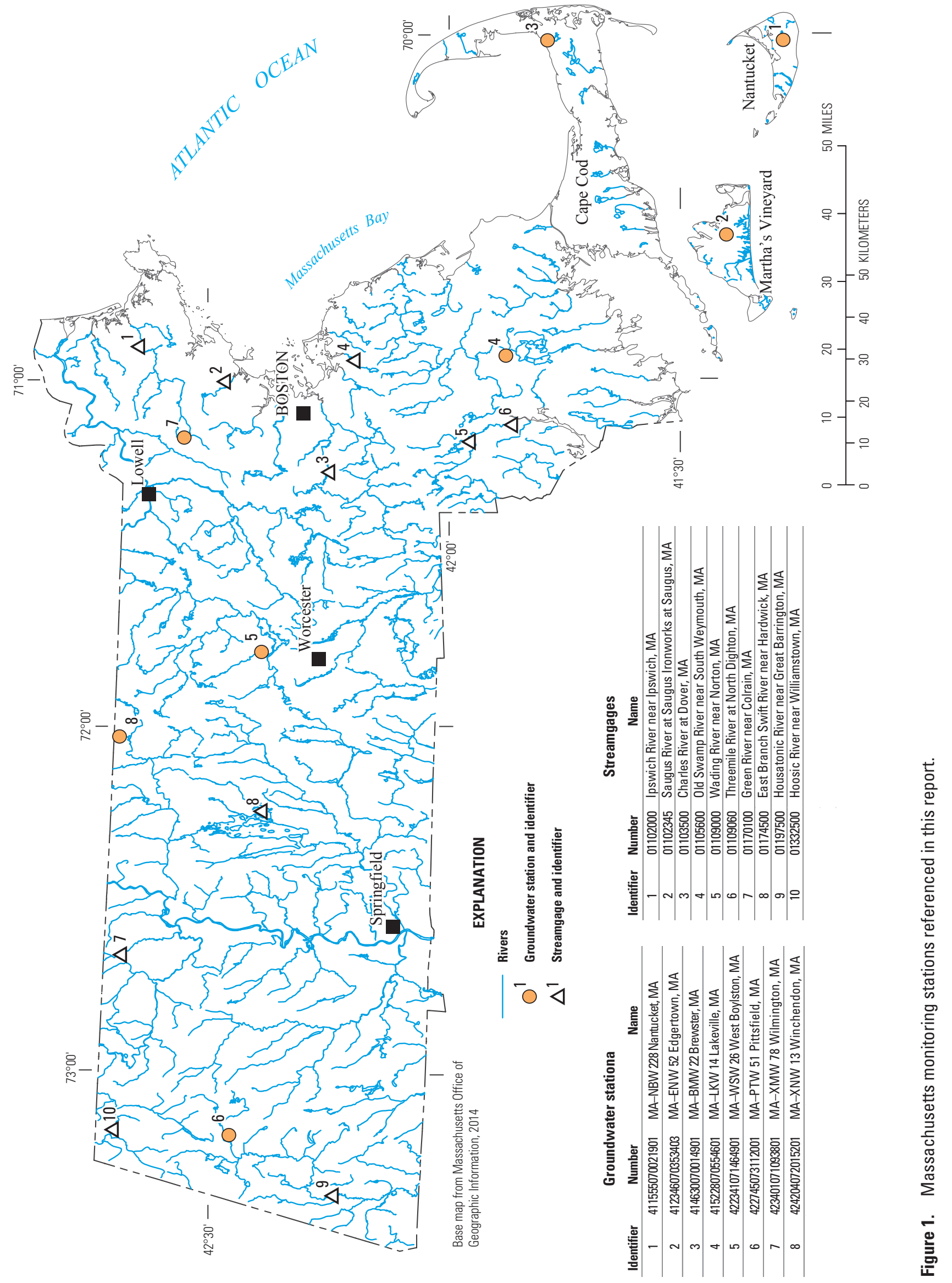




\section{Hydrologic Conditions in Massachusetts}

The hydrologic conditions in Massachusetts during water year 2014 are described in detail below, and comparisons are made to normal conditions. Normal conditions are defined in this report as the long-term average for the period of record. Analyses of data are made for precipitation, surface-water discharge, and groundwater levels.

\section{Precipitation}

The graphs in figures $2 \mathrm{~A}-\mathrm{F}$ show average annual cumulative precipitation and cumulative precipitation for water year 2014 in regions of Massachusetts. Figure 2G shows average annual cumulative precipitation and cumulative precipitation for water year 2014 for the State as a whole. The data presented in these figures were provided by the Massachusetts Department of Conservation and Recreation, Office of Water Resources (Linda Hutchins, written commun., 2014).

Cumulative precipitation throughout Massachusetts during water year 2014 ended below normal for the State as a whole (fig. 2G). Average annual cumulative precipitation in the Connecticut River Basin and the central and western regions of Massachusetts was about normal at the end of the water year (figs. 2A-C). The northeastern and southeastern regions of the State and Cape Cod ended the year below normal, cumulatively (figs. 2D-F). The effects of several consecutive months of lower than normal precipitation in these parts of the State recorded at numerous streamgages are discussed in the "Surface-Water Discharge" section.

\section{Surface-Water Discharge}

Discharge hydrographs for six representative streams in Massachusetts are shown in figures 3A-F. Each hydrograph shows the monthly mean discharge for water year 2014 and the monthly maximum, minimum, and mean discharges for the period of record for the station. Table 1 presents mean annual discharge for water years 2014 and 2013 (for comparison), expressed in units of cubic feet per second and as a percentage of the mean annual average for the period of record, for the six representative streams.

Monthly and annual rates of discharge in streams varied from below normal to above normal in Massachusetts during water year 2014 (figs. 3A-F; table 1). A new maximum monthly mean discharge, mostly caused by snowmelt and heavy localized precipitation, was recorded at East Branch Swift River near Hardwick during May 2014. The new record of 191 cubic feet per second $\left(\mathrm{ft}^{3} / \mathrm{s}\right)$ exceeds the previous record of $189 \mathrm{ft}^{3} / \mathrm{s}$ set in 1984 .
New minimum monthly mean discharges, caused by below normal precipitation, were recorded at four streamgages in the northeastern and southeastern regions of the State and Cape Cod (table 2). For example, a new minimum monthly mean discharge was recorded at Wading River near Norton during the month of September 2014. The new record of $0.84 \mathrm{ft}^{3} / \mathrm{s}$ exceeds the previous record of $1.76 \mathrm{ft}^{3} / \mathrm{s}$ set in 1930 .

\section{Groundwater Levels}

Groundwater hydrographs for eight representative wells in Massachusetts are shown in figures 4A to H. Each hydrograph shows the water year 2014 month-end water level and the maximum, minimum, and monthly median water levels for the period of record at that site.

Groundwater levels across the State ranged from below normal to above normal. No new record water levels were reported for any well in the State. Daily mean groundwaterlevel data for the 29 continuous-recording wells in the State can be obtained by visiting the USGS annual data report Web site (http://wdr.water.usgs.gov/). Month-end water levels, water-level statistics, and well characteristics for the 57 wells in the State that are part of the Climate Response Network can be obtained from the USGS groundwater watch Web site (http://groundwaterwatch.usgs.gov/NetMapT1L2. asp? $\mathrm{ncd}=\mathrm{crn} \& \mathrm{sc}=25)$. This information can also be obtained for the 72 wells in the State that are part of the Active Water Level Network (http://groundwaterwatch.usgs.gov/statemap. asp? $\mathrm{sc}=25 \& \mathrm{sa}=\mathrm{MA}$ ).

\section{Summary}

Precipitation and water-level conditions varied across Massachusetts. Annual cumulative precipitation was below normal for the State as a whole. Stream discharges ranged from below normal to normal to above normal with several sites reaching record-minimum monthly mean discharges and one reaching record-maximum monthly mean discharge. Groundwater levels ranged from below normal to above normal with no sites reaching new records during the year.

\section{Acknowledgments}

The author acknowledges the contributions of senior hydrologist Roy Socolow, senior hydrographer Linda Comeau, and hydrographers Robert Bradley, Christopher Bruet, Josh Combs, Emilie Nobles, Steve O'Brien, and Lance Ramsbey of the U.S. Geological Survey Hydrologic Surveillance Unit in Northborough, Massachusetts, for their efforts in data collection and record computations. 
A. Western region (period of record 1906-2014)

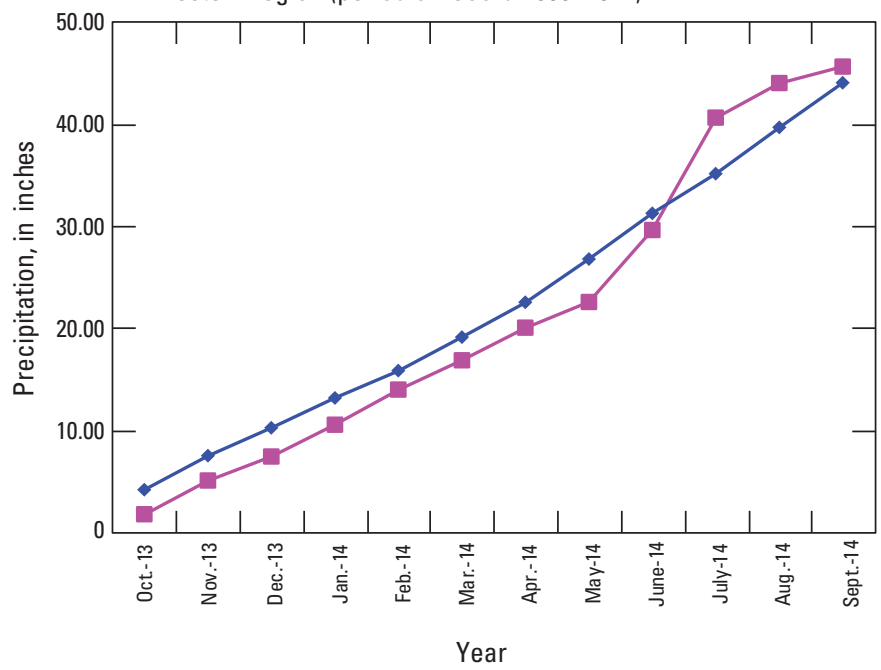

C. Central region (period of record 1872-2014)

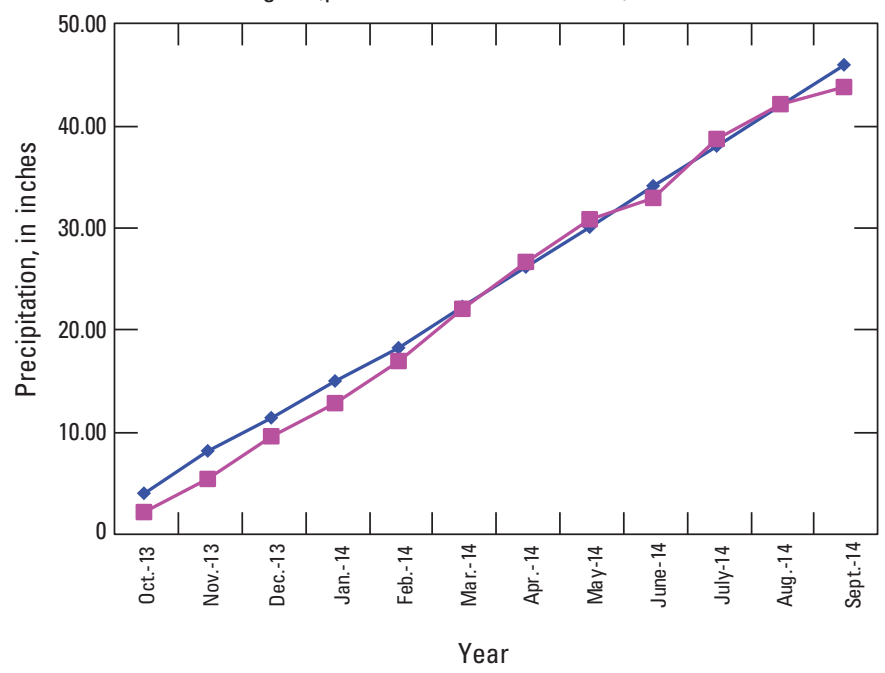

B. Connecticut River region (period of record 1838-2014)

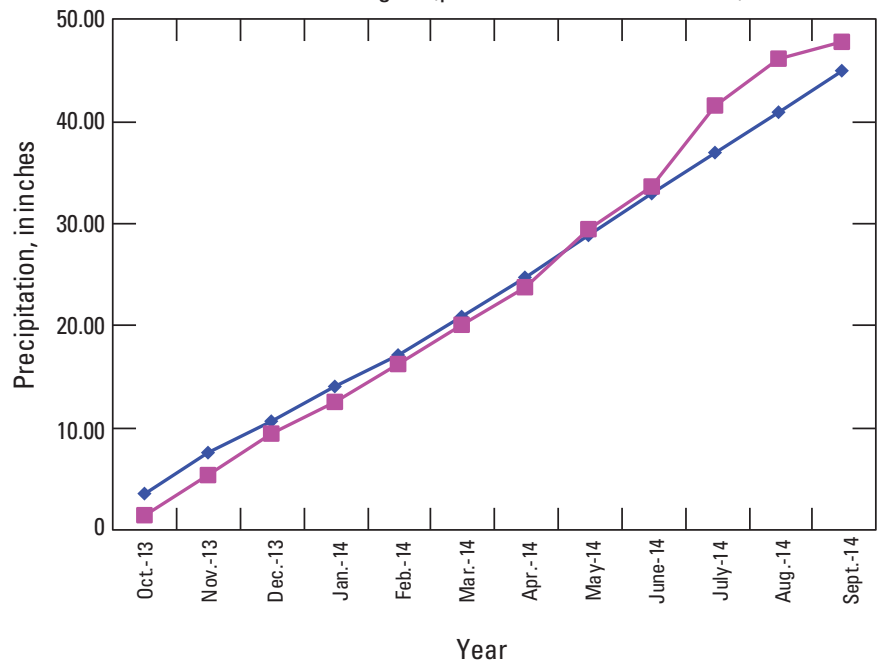

D. Northeastern region (period of record 1873-2014)

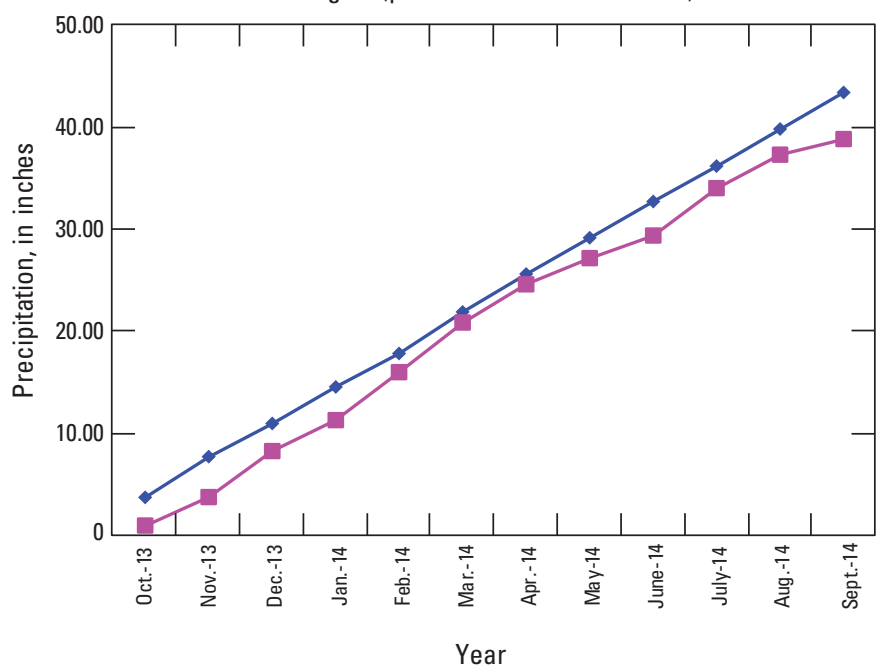

EXPLANATION

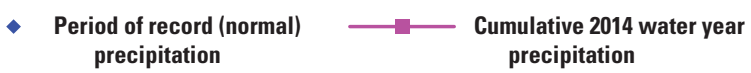

Figure 2. Average annual cumulative precipitation versus cumulative precipitation during water year 2014 for $A-F$, regions and $G$, the entire State of Massachusetts. 
E. Southeastern region (period of record 1887-2014)

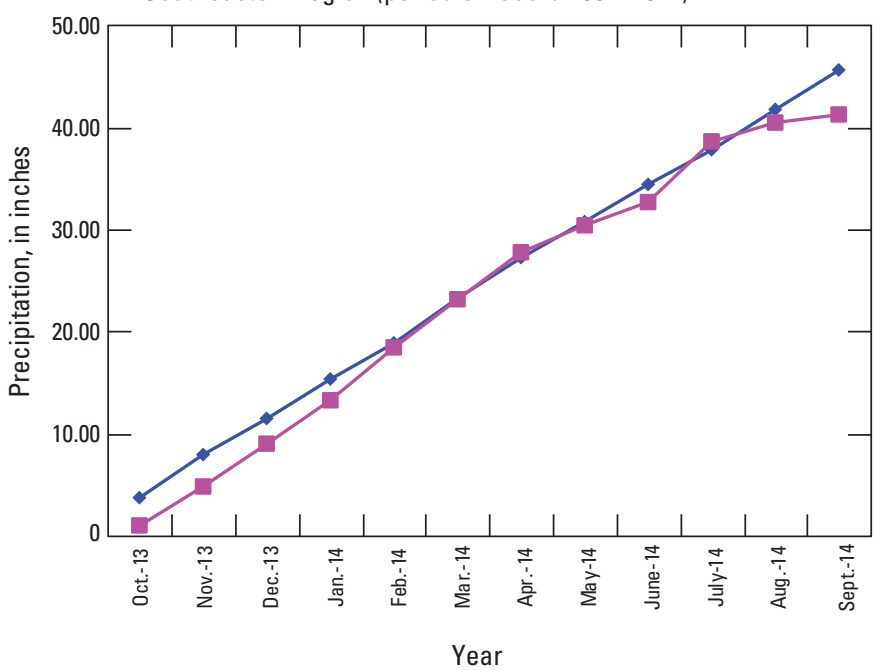

G. Entire State (period of record 1838-2014)

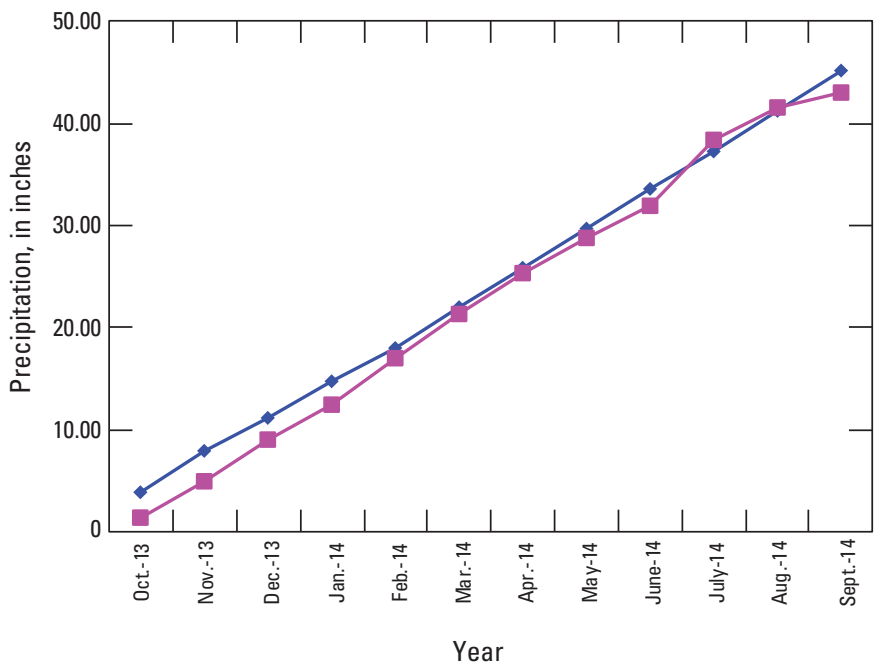

F. Cape Cod region (period of record 1919-2014)

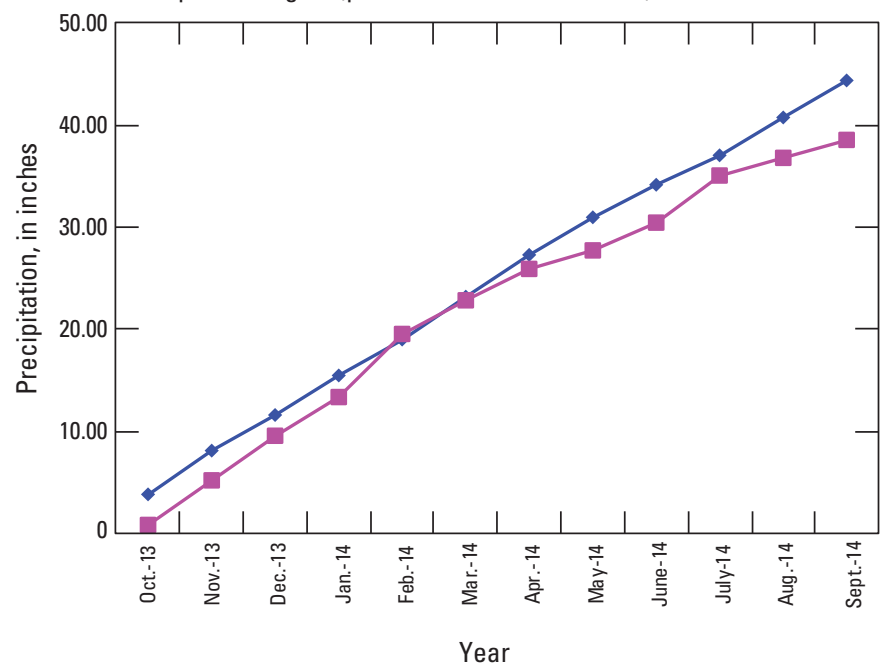

EXPLANATION

- Period of record (normal) $\longrightarrow$ Cumulative 2014 water year precipitation precipitation

Figure 2. Average annual cumulative precipitation versus cumulative precipitation during water year 2014 for $A-F$, regions and $G$, the entire State of Massachusetts.-Continued 
A. 01102000 Ipswich River near Ipswich, MA; drainage area, $125 \mathrm{mi}^{2}$; (period of record 1938-2014)

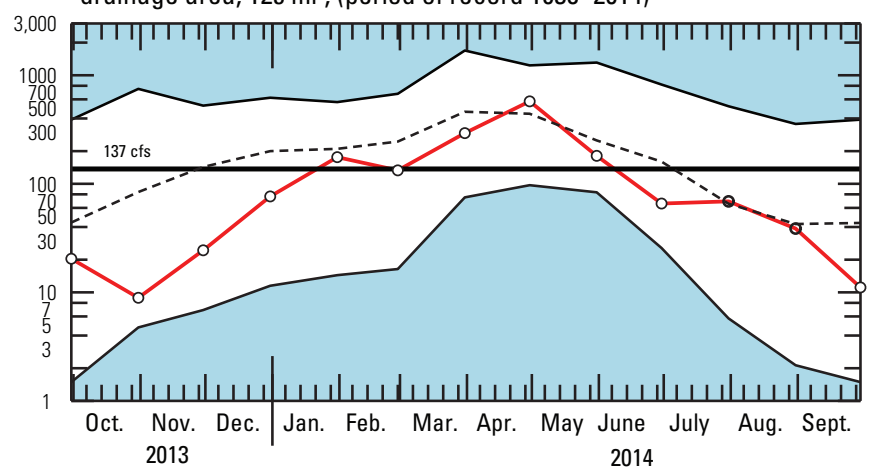

C. 01109000 Wading River near Norton, MA;

drainage area, $43.3 \mathrm{mi}^{2}$ (period of record 1925-2014)

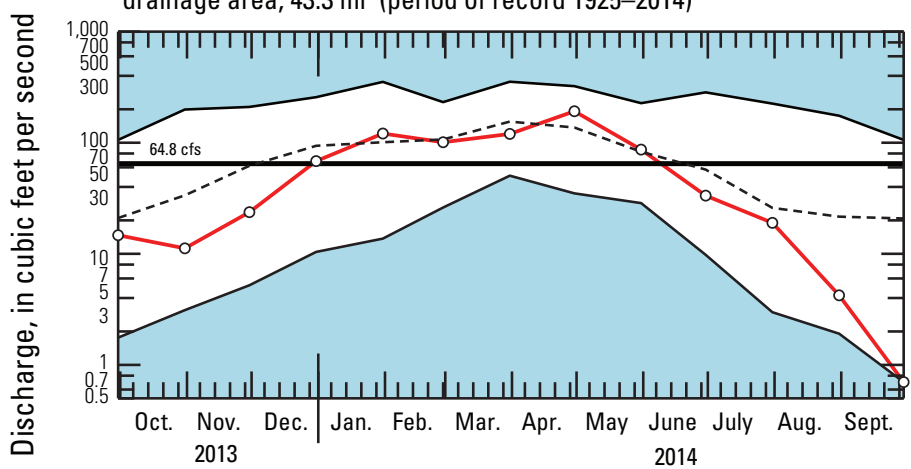

E. 01197500 Housatonic River near Great Barrington, MA; drainage area, $282 \mathrm{mi}^{2}$ (period of record 1913-2014)

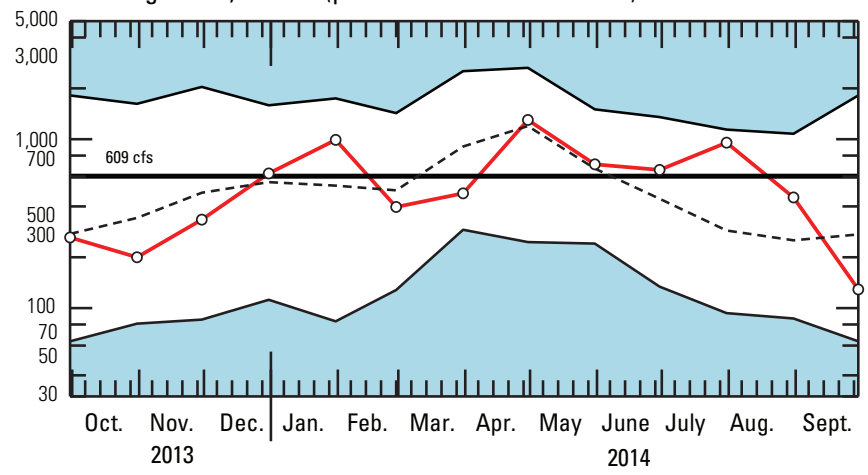

B. 01103500 Charles River at Dover, MA;

drainage area, $183 \mathrm{mi}^{2}$; (period of record 1938-2014)

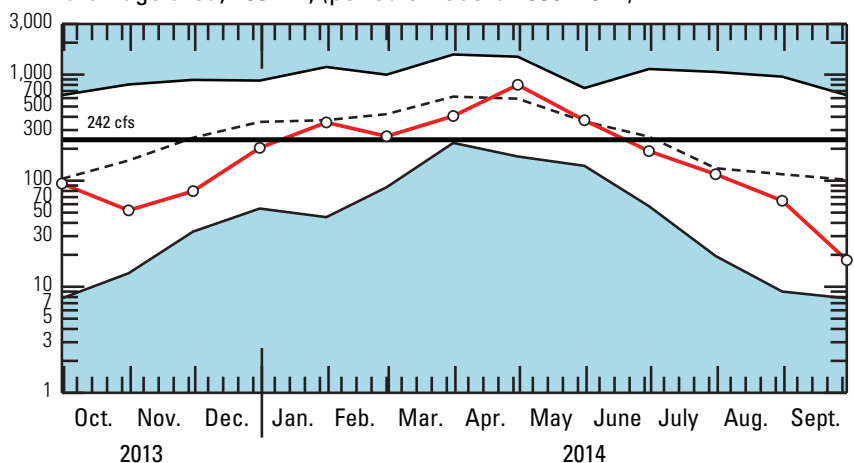

D. 01174500 East Branch Swift River near Hardwick, MA; drainage area, $43.7 \mathrm{mi}^{2}$; (period of record 1937-2014)

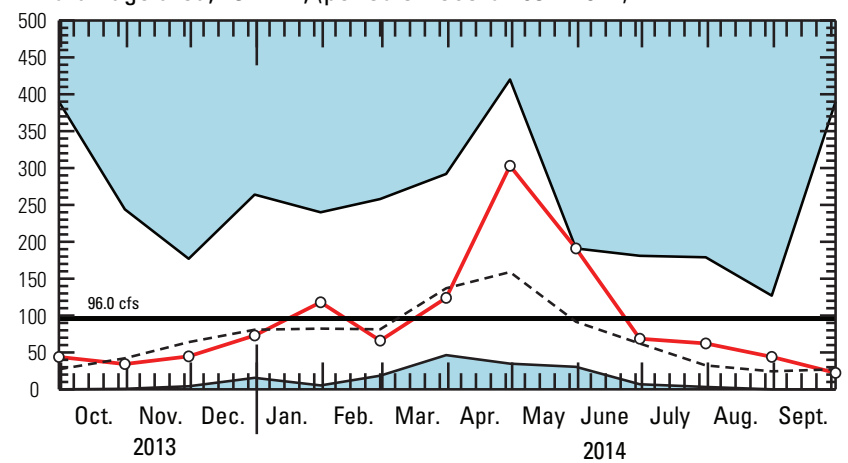

F. 01332500 Hoosic River near Williamstown, MA; drainage area, $126 \mathrm{mi}^{2}$ (period of record 1940-2014)

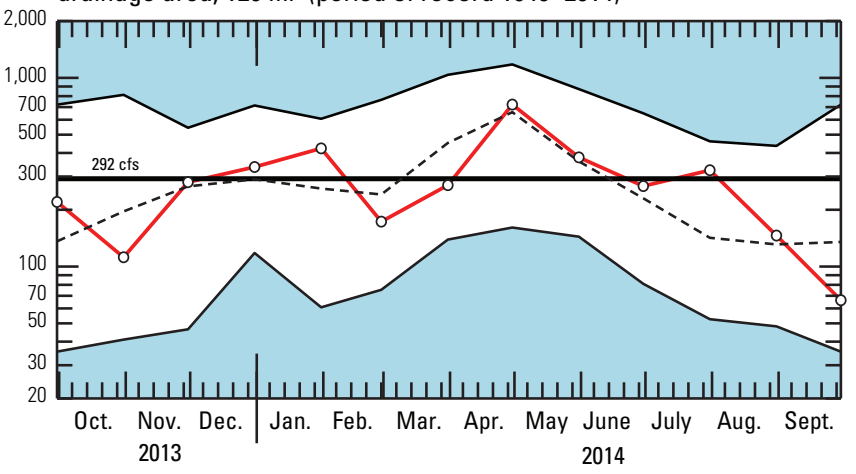

\section{EXPLANATION}

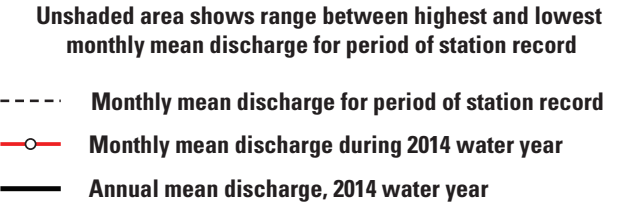

Figure 3. Discharge hydrographs for the six representative streams in Massachusetts. Each hydrograph shows the monthly mean discharge for water year 2014 compared with the monthly maximum, minimum, and mean discharges for the period of record for the site. $\mathrm{mi}^{2}$, square miles. 
Table 1. Mean annual discharge of selected streams in Massachusetts for water years 2014 and 2013 and for the period of record.

[USGS, U.S. Geological Survey]

\begin{tabular}{|c|c|c|c|c|c|c|c|}
\hline \multirow[b]{3}{*}{$\begin{array}{c}\text { USGS } \\
\text { station } \\
\text { number }\end{array}$} & \multirow[b]{3}{*}{$\begin{array}{l}\text { USGS } \\
\text { station name }\end{array}$} & \multicolumn{4}{|c|}{ Mean discharge } & \multirow{2}{*}{\multicolumn{2}{|c|}{$\begin{array}{l}\text { Mean annual discharge } \\
\text { for period of record }\end{array}$}} \\
\hline & & \multicolumn{2}{|c|}{ Water year 2014} & \multicolumn{2}{|c|}{ Water year 2013} & & \\
\hline & & $\begin{array}{l}\text { Discharge, } \\
\text { in cubic feet } \\
\text { per second }\end{array}$ & $\begin{array}{l}\text { Percentage of } \\
\text { mean annual } \\
\text { discharge for } \\
\text { period of } \\
\text { record }\end{array}$ & $\begin{array}{c}\text { Discharge, } \\
\text { in cubic feet } \\
\text { per second }\end{array}$ & $\begin{array}{l}\text { Percentage of } \\
\text { mean annual } \\
\text { discharge for } \\
\text { period of } \\
\text { record }\end{array}$ & $\begin{array}{l}\text { Period } \\
\text { of record }\end{array}$ & $\begin{array}{l}\text { Discharge, in } \\
\text { cubic feet per } \\
\text { second }\end{array}$ \\
\hline 01103500 & Charles River at Dover, MA & 242 & 78 & 330 & 106 & $1938-2014$ & 311 \\
\hline 01109000 & Wading River near Norton, MA & 64.8 & 87 & 87.0 & 116 & $1925-2014$ & 74.7 \\
\hline 01174500 & $\begin{array}{l}\text { East Branch Switft River near } \\
\text { Hardwick, MA }\end{array}$ & 96.0 & 131 & 71.8 & 98 & $1937-2014$ & 73.4 \\
\hline
\end{tabular}

Table 2. Record-minimum monthly mean discharges in Massachusetts during water year 2014 compared with the previous records for the period of record.

[USGS, U.S. Geological Survey]

\begin{tabular}{|c|c|c|c|c|c|c|}
\hline $\begin{array}{l}\text { USGS station } \\
\text { number }\end{array}$ & $\begin{array}{c}\text { USGS } \\
\text { station name }\end{array}$ & $\begin{array}{l}\text { Period of } \\
\text { record }\end{array}$ & $\begin{array}{l}\text { Month of } \\
\text { record } \\
\text { minimum }\end{array}$ & $\begin{array}{l}\text { Water year } 2014 \\
\text { minimum monthly } \\
\text { mean discharge } \\
\text { (cubic feet per } \\
\text { second) }\end{array}$ & $\begin{array}{l}\text { Year of previous } \\
\text { record-minimum } \\
\text { monthly mean } \\
\text { discharge }\end{array}$ & $\begin{array}{l}\text { Historical mini- } \\
\text { mum monthly mean } \\
\text { discharge } \\
\text { (cubic feet per } \\
\text { second) }\end{array}$ \\
\hline 01102345 & $\begin{array}{l}\text { Saugus River at Saugus } \\
\text { Ironworks at Saugus, MA }\end{array}$ & 1994-2014 & October & 1.57 & 1998 & 2.35 \\
\hline Do. & Do. & Do. & September & 0.15 & 1980 & 0.18 \\
\hline 01109000 & $\begin{array}{l}\text { Wading River near Norton, } \\
\text { MA }\end{array}$ & $1925-2014$ & September & 0.84 & 1930 & 1.76 \\
\hline 01109060 & $\begin{array}{l}\text { Threemile River at North } \\
\text { Dighton, MA }\end{array}$ & 1966-2014 & September & 5.83 & 1993 & 10.9 \\
\hline
\end{tabular}




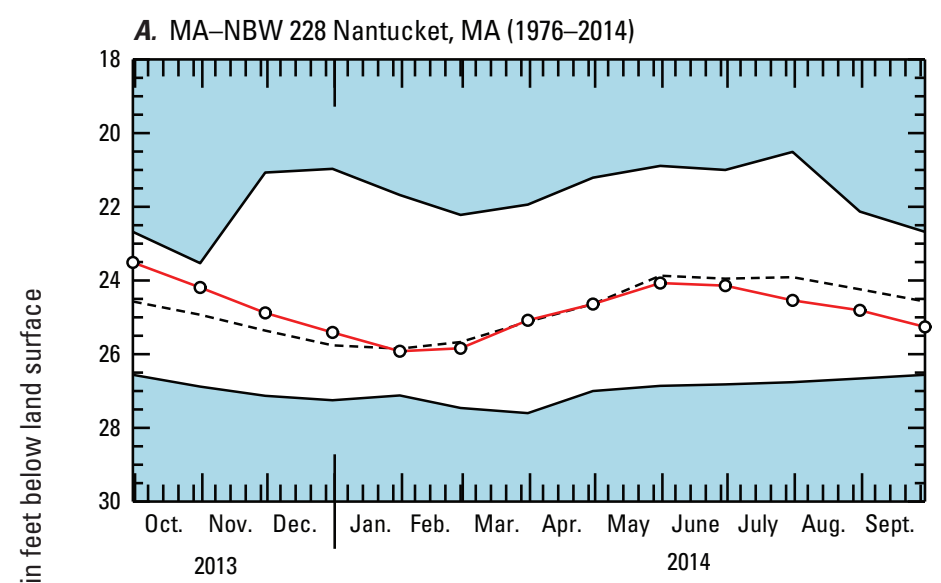

B. MA-ENW 52 Edgartown, MA (1976-2014)

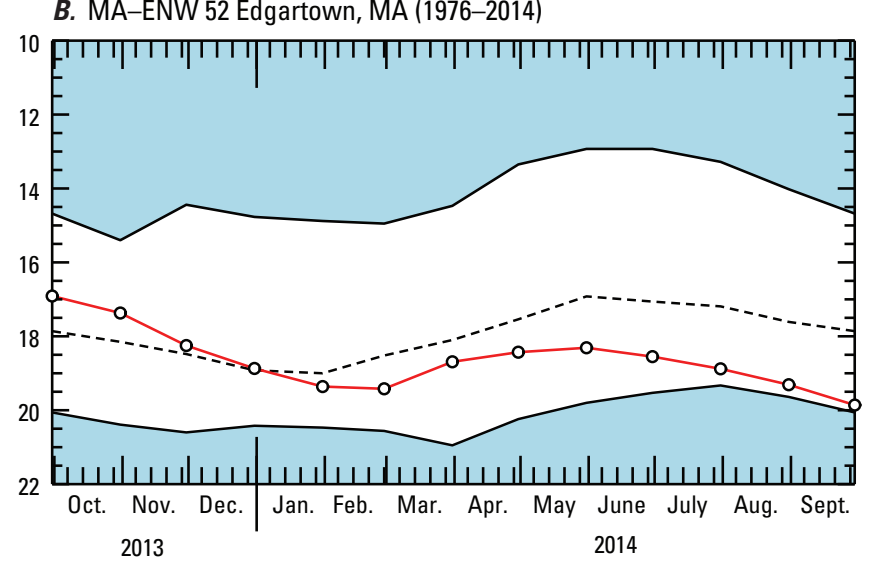

C. MA-LKW 14 Lakeville, MA (1964-2014)

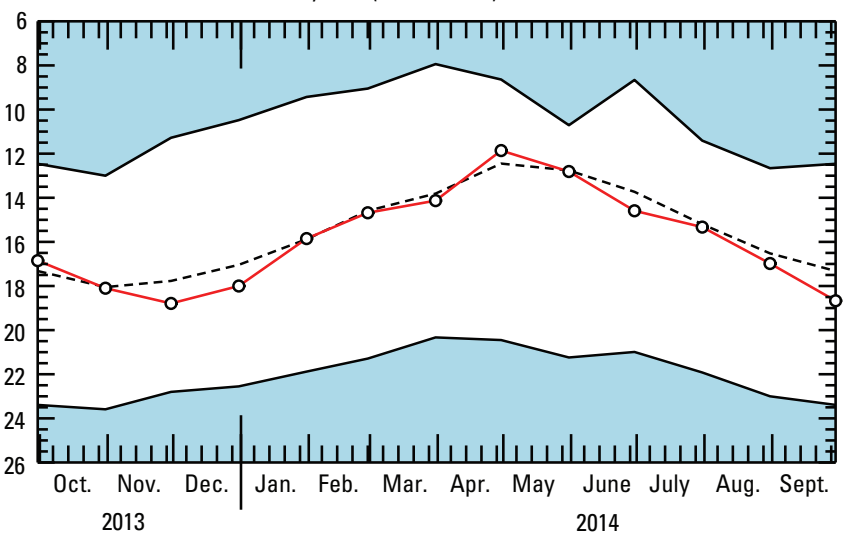

D. MA-BMW 22 Brewster, MA (1962-2014)

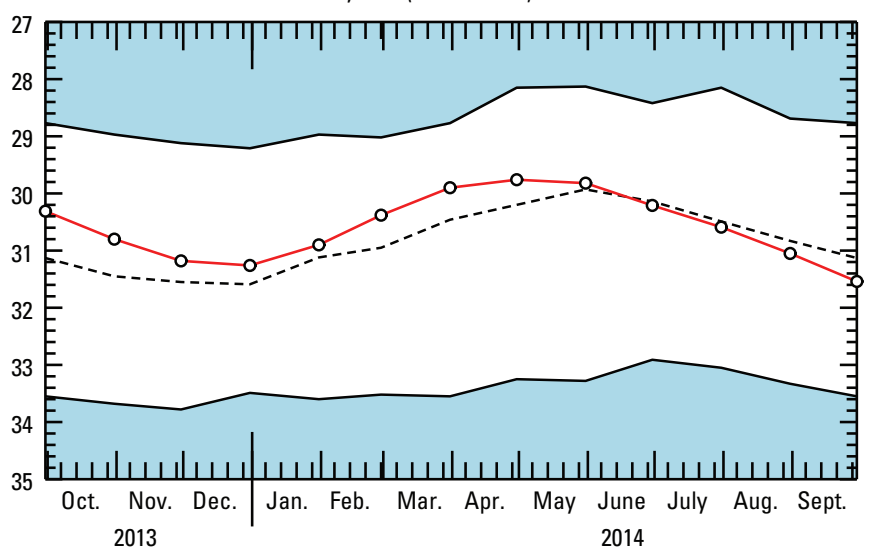

\section{EXPLANATION}

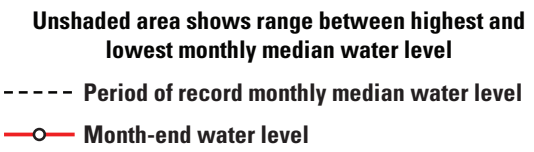

Figure 4. Groundwater hydrographs for the eight representative wells in Massachusetts. Each hydrograph shows the water year 2014 month-end water level compared to the maximum, minimum, and mean monthly median water level for the period of record at that site. 
E. MA-XMW 78 Wilmington, MA (1951-2014)

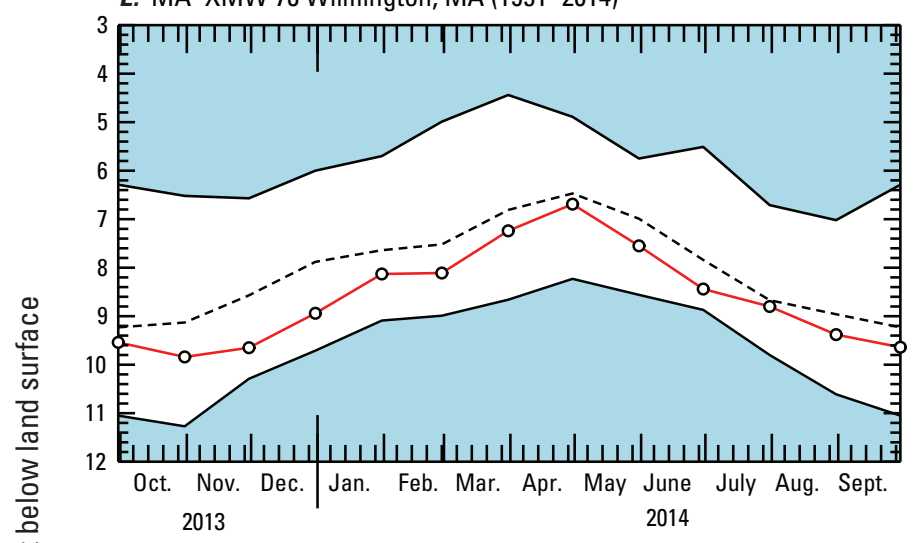

G. MA-XNW 13 Winchendon, MA (1939-2014)

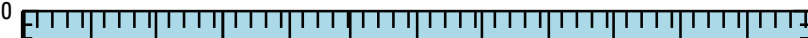

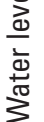

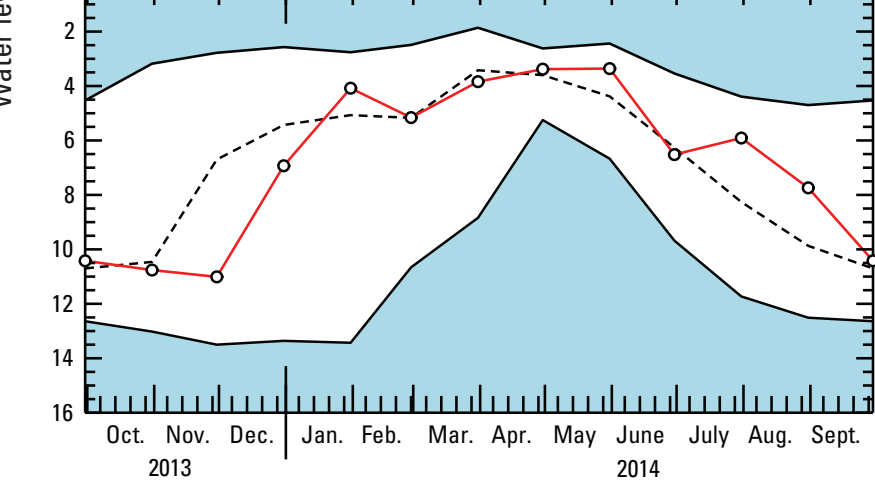

F. MA-WSW 26 West Boylston, MA (1995-2014)

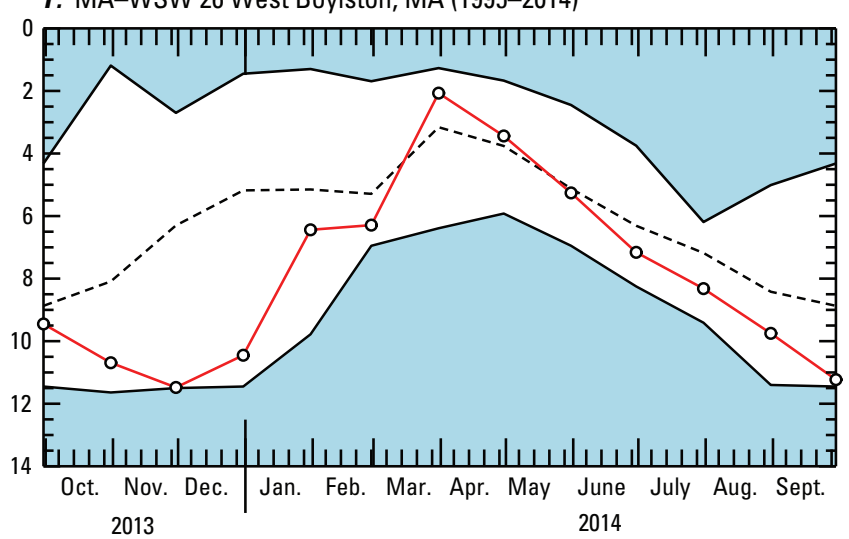

H. MA-PTW 51 Pittsfield, MA (1963-2014)

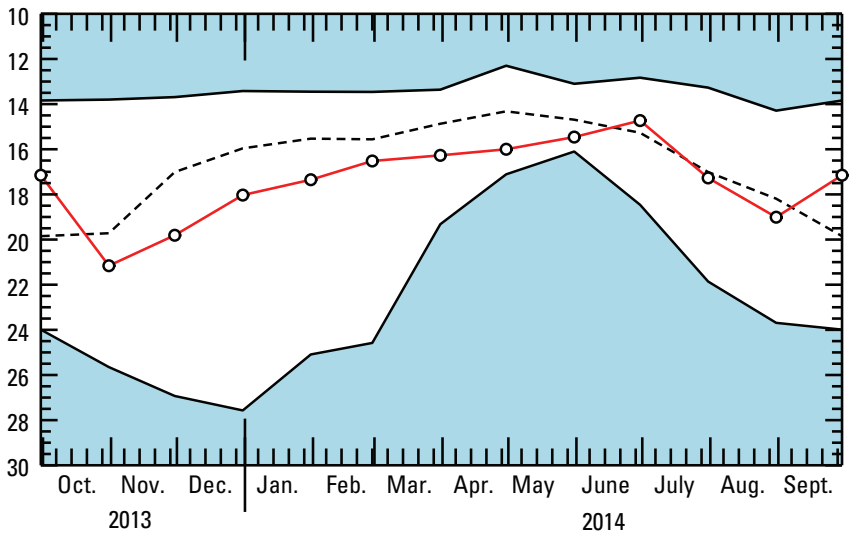

EXPLANATION

Unshaded area shows range between highest and lowest monthly median water level

- - - - Period of record monthly median water level

- - Month-end water level

Figure 4. Groundwater hydrographs for the eight representative wells in Massachusetts. Each hydrograph shows the water year 2014 month-end water level compared to the maximum, minimum, and mean monthly median water level for the period of record at that site.-Continued 
Prepared by the Pembroke Publishing Service Center.

For more information concerning this report, contact:

Director

New England Water Science Center

U.S. Geological Survey

10 Bearfoot Road

Northborough, MA 01532

dc_nweng@usgs.gov

or visit our Web site at:

http://ma.water.usgs.gov 


\section{$\frac{\mathbb{2}}{3}$}

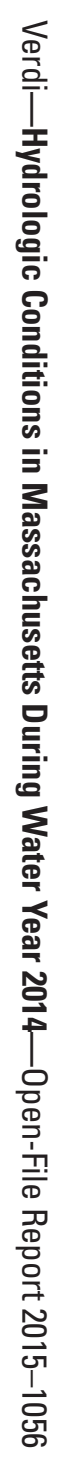

6 Printed on recycled paper 